\title{
Linking Customer Motivations to Customer Engagement in Fashion Facebook Brand Pages
}

South Asian Journal of Business Insights 2021,1(2), 03-23. ISSN 2773-7012(print) ISSN 2773-6997(online) (c) 2021, Faculty of Management and Finance University of Ruhuna, Sri Lanka

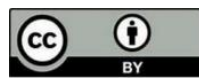

\section{Ranaweera, Hasini Virajini*}

Department of Marketing, University of Ruhuna, Sri Lanka

\author{
de Silva, Thanuka Mahesha
}

Department of Marketing, University of Ruhuna, Sri Lanka

desilvathanuka@gmail.com

\begin{abstract}
This study aims to analyse the effects of customer motivations, namely information motive, entertainment motive, and social interaction motive on different dimensions of customer engagement (cognition, affection, and activation) in the context of Fashion Facebook Brand Pages (FFBPs). The data were collected from a convenience sample of 258 undergraduates in Sri Lanka using a printed and an online questionnaire and they were analysed using SPSS 21.0 and AMOS 21.0. The data analysis revealed that information motive had effects on cognition and affection whilst no effect on activation. In terms of influence of entertainment motive on customer engagement, the study found that entertainment was positively related to cognition and activation. However, there was no effect from entertainment motive to affection in the realm of FFBPs. Interestingly, the results highlighted that the social interaction motive was positively related to all three dimensions of customer engagement. The novelty of this paper is that, according to Uses \& Gratifications (U\&G) theory, the study develops a conceptual model integrating customer motivations and different components of customer engagement in the context of FFBPs.
\end{abstract}

Keywords: Customer Engagement, Entertainment, Facebook Brand Pages, Information, Social Interaction

\footnotetext{
* Corresponding Author- hasiniranaweera4@gmail.com
} 
Introduction

Social media platforms provide a significant avenue for users to engage with firms (Baird \& Parasnis, 2011). Hence, in order to expand the overall communication strategy, companies are investing in social media platforms (de Silva, 2019a). Facebook is undoubtedly the widely used social media platform by the marketers (Arenas, Ramirez, \& Rondan, 2013) in Sri Lanka (de Silva, 2021), and is considered as the most popular social networking site (SNS) (Lipsman, Mudd, Rich, \& Bruich, 2012). The literature suggests that Facebook brand pages (FBPs) provide customers with interactive experiences (de Silva, 2019a), thus facilitating customer-to-customer interactions in the context of fashion FBPs (FFBPs) (McCormick \& Livett, 2012; de Silva, 2019a).

In this digital era, there is a large number of FFBPs in Sri Lanka (Rajapaksha \& Thilina, 2019); however, these FFBP marketers blindly run behind the number of likes, comments, and shares without knowing the value of engaging customers to strengthen the customerbrand relationships (de Silva, 2019a). Customer engagement can be viewed as the mechanism through which customer value is created to the organization, either through direct or indirect contribution (Pansari \& Kumar, 2017). Accordingly, cognition, affection, and activation dimensions can be identified as the different levels of customer engagement (Brodie, llic, Juric, \& Hollebeek, 2013). The literature suggests that when a customer has a high affective commitment to a fashion brand, the customer might be motivated to continuously maintain the relationship with the brand (Choi, Liu, Liu, Mak, \& To, 2010). In the recent literature, more attention was centred upon the behavioural perspective of customer engagement in the context of FBPs (Rodriguez \& Fernandez, 2016; Song, Moon, \& Kim, 2019; de Silva, 2021), while the multidimensional nature of customer engagement was overlooked. Notably, although past research endeavored to identify the factors influencing customer engagement, studies that attempted to analyse the effects of different customer motivations on different dimensions of customer engagement are still scant. Even though the multidimensional nature of customer engagement has gained more attention among scholars in the present digital era (Pansari, 2017; Hollebeek, Juric, \& Tang, 2017; Carlson, Rahman, Taylor, \& Voola, 2019), further investigations are needed to comprehensively understand the multidimensional nature of customer engagement (Hollebeek et al., 2017). The literature further suggests that fashion retailers present their brands via the FFBPs to encourage customer engagement, and they have become the most effective social media strategy available for fashion brands (Chang \& Fan, 2017). Fashion retail brands are getting more digital presence in the Sri Lankan context (Rajapaksha \& Thilina, 2019; de Silva, 2019a; Muniweera, Balawardhana, Rajapaksha, Chamara, \& Jayasuriya, 2020; de Silva, 2021; Gopura \& Kothalawala, 2021). However, FBPs are used as a promotional technique in the Sri Lankan context, instead of driving customer engagement as a relationship building tool (de Silva, 2019a; de Silva, 2021), resulting in a low level of average customer engagement rate (de Silva, 2019a; de Silva, 2021). Given the growing importance of FFBPs as an effective social media strategy and the dearth of research that links customer motivations with different dimensions of customer 
engagement, building on the U\&G theory, it is expected to analyse the effects of customer motivations on cognitive, affective and, activation dimensions of customer engagement in the context of FFBPs in Sri Lanka through this study.

This paper is organized as follows. The next section reviews the literature on customer engagement, followed by the development of the conceptual framework and the study hypotheses. Then, the research methods and data analysis are presented in the subsequent two sections. Later, the paper discusses the findings in light of the findings of similar work in the area, followed by theoretical and managerial implications. Finally, the study provides the limitations and directions for future research.

\section{Literature Review}

U\&G theory was one of the first approaches to concern the role of the individuals in media choice, indicating that the audience choose media to satisfy different gratifications (Ku, Chu, \& Tseng, 2013). The need for information, the need for entertainment, and the need for social interaction have been inquired in the literature that has investigated individuals' choices for online media based on the theoretical underpinning of U\&G theory (Whiting \& Williams, 2013). Accordingly, this study mainly focuses on the information, entertainment, and social interaction motives in relation to the U\&G theory.

\section{Uses and Gratifications (U\&G) Theory}

In the 1940s, U\&G theory was introduced to measure the relationship between mass media and audience behaviours (Anabel, 2012). This U\&G theory explains why and how individuals use different types of media to satisfy their motives (Katz \& Foulkes, 1962). As such, individuals evaluate the gratifications of using different media when they select a media channel (Lee \& Ma, 2012). According to scholars, the behavioural aspect of customer engagement includes activities such as active searching of brand information and following the social media updates of the brand (Dwivedi, 2015). Moreover, U\&G theory describes specific behaviours of customers who use different features of social media (Smock, Ellison, Lampe, \& Wohn, 2011). The literature suggests that information motive, entertainment motive, and the social interaction motive are the primary list of customer motivations that lead to customer engagement in the context of FBPs (de Silva, 2019b).

\section{Facebook Brand Pages (FBPs)}

Brand communities can create substantial value for consumers (Schau \& Gilly, 2009). Social media outlets (e.g., Facebook) provide significant tools for firms to engage with customers through "brand fan pages" (Beukeboom, Kerkhof, \& Vries, 2015). Companies are able build relationships, engage with customers, enhance brand loyalty, and promote the brand through the use of FBPs (Mochon, Johnson, Schwartz, \& Ariely, 2017). In the same way, companies are able to take the advantage of strong capabilities of social media by 
designing multidimensional customer experiences through their brand pages (Shao \& Ross, 2015). Hence, as a part of social media marketing strategy, marketers are capitalizing these interactive FBPs to strengthen their relationships with customers.

\section{Customer Engagement}

In academia, customer engagement has been defined in different ways. Customer engagement is "the mechanics of a customer's value addition to the firm, either through direct or/and indirect contribution" (Pansari \& Kumar, 2017). Research studies related to "consumer engagement" and consumers' social media behaviour have become a key research area among the academics in the past few years (Hollebeek, 2011). Hollebeek et al. (2017) noted that customer engagement was a way of developing/enhancing customer interactions and building customer relationships. Customer engagement is a set of measurable behaviours or measurable actions that customers present on social media (Barger, Peltier, \& Schultz, 2016). Customer engagement in social media leads to favourable impression of the firm (Frimpong \& McLean, 2018), and this multidimensional concept includes cognitive, emotional (affection), and behavioural (activation) components (Brodie et al., 2013). The cognition indicates the level of customer mental investments with the brand while affection refers to the customer's level of positive feeling with the brand (Nyadzayo, Leckie, \& Johnson, 2016). The behavioural dimension of customer engagement represents the customer's preferences to spend time, energy, and effort on brand-related activities (Nyadzayo et al., 2016). According to literature, scholars have shown that consumers prefer to invest their effort (behaviour) in order to maintain the interaction, to be mentally addicted (cognition) in the interaction, and enthusiastically to be inspired (affective) in the process of interaction (Dwivedi, 2015).

\section{Information}

Scholars investigated the information seeking as the main gratification of customer engagement (Hicks, Comp, Horovitz, Hovarter, Miki, \& Beven, 2012). Similarly, some studies have confirmed that information includes product specifications, company information, and extensive information on the brand (Hoekstra, Huizzingh, Bijmolt, \& Krawczyk, 2015). So, it is significant to note that brand communities provide information for participants, and it will assist to enhance the interactions among customers (Habibi, Laroche, \& Richard, 2014).

\section{Entertainment}

Entertainment value is primarily concerned with the functionality of online customer brand interactions (Enginkaya \& Yilmaz, 2014). According to literature, aesthetics is an important environmental entertainment signal for influencing customer behaviour (Porat \& Tractinsky, 2012). Environmental cues or signals such as attractive products, colours, music, and animation can enhance the entertainment for online stores (Shukla, Sharma, \& Swami, 2011). Using U\&G theory, scholars have demonstrated that entertainment motive had a greater importance for determining the success of OBCs (Raacke \& Bonds, 2008). 
Ranaweera, Hasini Virajini and de Silva, Thanuka Mahesha

Social Interaction

Social interaction plays a significant role in the context of OBCs (Kuo \& Feng, 2013). In social interactions, consumers use brands to create self-identity and through Facebook likes consumers link themselves to the brands, and finally it creates an important impression on others (Schau \& Gilly, 2003). According to literature, social interactional motivation provides a greater opportunity to share product and brand-related thoughts and opinions among consumers (Chu \& Kim, 2011). Furthermore, past studies have already acknowledged the role of social interaction motive in influencing customer engagement in the realm of FBPs (de Silva, 2019a; 2019b).

\section{Hypotheses Development}

In the context of FBPs, scholars have demonstrated that there is a relationship between information motive and customer engagement (de Vries, Gensler, \& Leeflang, 2012; Enginkaya \& Yilmaz, 2014; de Silva, 2019a). Customers make buying decisions after reading brand-related content such as price, discounts, quality, guarantees, and other product-related information (Muntinga, Moorman, \& Smit, 2011). To create strong and positive brand knowledge in existing and potential consumers' minds, brands need to communicate their brand-related information on their FBPs (Seo \& Park, 2018). Consequently, customers engage with different brand-related content through activities such as reading, downloading brand-related content, listening to the content, and viewing the content on the brand pages. The literature highlights that highly engaged customers are willing to use FBPs to search for brand-related content and brand-related information (Carlson et al., 2019; Carlson, Wyllie, Rahman, \& Voola, 2019). The motivation of information includes seeking about new product development and trends, products and services, events, and experienced customers' opinions that can influence their purchases (Tsai \& Men, 2017). When a brand page consists of pieces of necessary information, it is likely to increase the consumption of information and enhance the level of engagement (Dolan, Conduit, Fahy, \& Goodman, 2016). Moreover, when a brand post contains more information that the customer seeks, then the customer's motivation to engage in the OBC is finally met (de Vries et al., 2012). Scholars found that information seeking leads to online shopping among Facebook users (Kang \& Johnson, 2015), and searching for information is the main gratification in the realm of OBCs (Muntinga et al., 2011; Zaglia, 2013). Previous research studies have shown that distributing reliable information through FBPs is deemed to be an effective strategy (Enginkaya \& Yilmaz, 2014), and it can help marketers in engaging customers on their FBP. Accordingly, it can be hypothesized that,

$\mathrm{H} 1 \mathrm{a}$ : Information motive has an impact on the cognition component of customer engagement

$\mathrm{H} 1 \mathrm{~b}$ : Information motive has an impact on the affection component of customer engagement 
H1c: Information motive has an impact on the activation component of customer engagement

Entertainment occurs when marketers utilize FBPs to generate playful, fun, and joyful customer experiences through the use of pictures, games, music, contests, and videos (Cheung, Pires, \& Rosenberger, 2019). The motivation of entertainment consists of fun, pleasure, enjoyment, and escapism (Tsai \& Men, 2017), which encourage individuals to engage on brand pages (Cheung, Chiu, \& Lee, 2011). Scholars have found that the entertainment serves as a strong factor influencing the attitude towards SNSs (Curran \& Lennon, 2011), and it is crucial for achieving brand page popularity via number of likes on FBPs (de Vries et al., 2012). Consumers perceive fun and joy when FBPs provide entertaining experiences such as games and video sharing (Manthiou, Chiang, \& Tang, 2013), which can create a cognition of customer intimacy (Dessart, Veloutsou, \& MorganThomas, 2015). Moreover, entertaining brand posts can enhance the level of customer engagement such as liking, commenting, and sharing (Cvijikj \& Michahelles, 2013; Poyry, Parvinen, \& Malmivaara, 2013). Affective commitment executes as an emotional as well as psychological obstacle to switch a brand, and therefore customers' emotional attachment encourage customer interactions with the brand (Richard \& Zhang, 2012). The literature suggests that entertainment is critical in spurring online customer interactions (Enginkaya \& Yilmaz, 2014), and encouraging the creation of user-generated content (Shao, 2009). Customers are more likely to engage with liking behaviours for the entertaining content on FBPs (Tafesse, 2015), and it drives customers to engage with online retail brands (Parihar, Dawra, \& Sahay, 2018). Therefore, it is hypothesized that,

H2a: Entertainment motive has an impact on the cognition component of customer engagement

H2b: Entertainment motive has an impact on the affective component of customer engagement

H2c: Entertainment motive has an impact on the activation component of customer engagement

Social interactions are important for attracting customers toward FBPs (Jahn \& Kunz, 2012). According to previous research, there are three levels of interactions namely, "likes", "comments" and "shares" (Peters, Chen, Kaplan, Ognibeni, \& Pauwels, 2012). Customer brand-related interactions are important to improve the cognitive understanding of customers as well as the cognitive understanding of brand benefits and product attributes (Cheung et al., 2020). The improvement of customers' cognitive understanding helps to encourage interactions such as messaging, commenting, and sharing of brandrelated information among individuals (Seo \& Park, 2018). Especially, a large number of customers get brand-related information by following FBPs (Ismail, 2017), motivating them to interact with relevant brands, sharing brand-related content and reacting on content (Lee, Chan, Chong, \& Thadani, 2019). Customers search for advantages from the social interactions with like-minded customers in the social media brand pages (Dimitiadis 
Ranaweera, Hasini Virajini and de Silva, Thanuka Mahesha

\& Tsimonis, 2014). Social interactional gratification leads customers to actively engage on FBPs via creating brand-related content (Vale \& Fernandes, 2018).

In the context of brand-consumer interactions, the promotions and incentives can be identified as the new interactional methods (Rohm, Kaltcheva, \& Milne, 2013). The large volume of interactions helped to generate a series of interactions (Lima, Irigaray, \& Lourenco, 2018). These interactions include different behaviours such as providing feedback and comments, participation in online discussions etc. (Ko, Cho, \& Roberts, 2005). Scholars have shown that social interaction gratification was of greater importance for the creation of user-generated content (Daugherty, Eastin, \& Bright, 2008). Moreover, social interaction involves motivation such as seeking support, connecting with friends, family, and society, gaining peer support, and meeting interesting people (Park, Kee, \& Valenzuela, 2009). Thus, it is hypothesized that,

H3a: Social Interaction motive has an impact on the cognition component of customer engagement

$\mathrm{H} 3 \mathrm{~b}$ : Social interaction motive has an impact on the affection component of customer engagement

H3c: Social interaction motive has an impact on the activation component of customer engagement

The conceptual framework with hypothesized relationships is depicted in Figure 1.

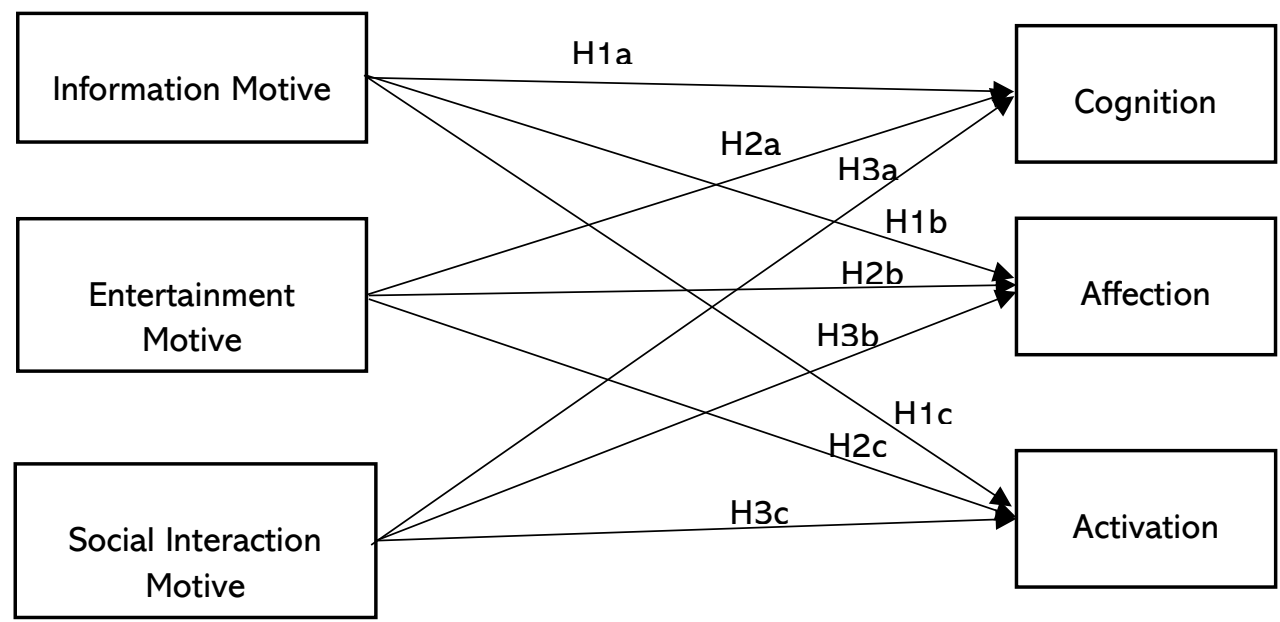

Figure 1: Conceptual Framework 


\section{Research Methods}

\section{Study Design and Participants}

In order to avoid non-response bias information, the data were collected from both online and printed questionnaires, from Sri Lankan undergraduates, who have been following FBPs in Sri Lanka. The sample included the undergraduates from top three state universities in Sri Lanka; University of Ruhuna, University of Sri Jayewardenepura, and University of Colombo (de Silva, 2021), who have been following at least a single FFBP. Young adults aged between 18-28 years were included in the sample since they were considered to be the heavy users of social media (Park et al., 2009; de Silva, 2019a). The data collection lasted for a period of three weeks, from 5th of February to 25th of February in 2020. Since an accessible sampling frame was not available, consistent with the past literature (de Silva, 2019a; de Silva, 2019b), the study used convenience sampling technique, and respondents were asked to respond by keeping in mind the most important FFBP for them in answering the scale items. Moreover, the present research study concerned with the deductive approach, and the research strategy was a survey.

The pretesting was a necessary task before employing the questionnaire (Schaller, Malhotra, \& Patil, 2017). Before collecting the data, the questionnaire was pretested by conducting a pre-test among few respondents. Overall, 258 usable responses were collected, which exceeded the minimum requirement for sample size (Stevens, 2009: 16 items $* 15=240)$. Among the respondents, $45.3 \%$ of respondents were males and the rest of the $54.7 \%$ respondents were females. Out of 258 respondents, the majority is from the age group of $24-28$, which is $65.1 \%$ of total respondents. In terms of FFBP visiting frequency, the majority of the respondents (49.6\%) visit the FFBP weekly. Table 1 provides a summary of the respondent characteristics.

\section{Measurements}

The questionnaire included two sections named as section I and section II. Section I included the independent variables (information, entertainment, and social interaction) and dependent variable of customer engagement that consisted of cognition, affection, and activation components. Section II included questions related to respondent general Facebook usage and demographic characteristics. Respondents were asked to respond on five-point Likert scales to measure the items of the measures. The five-point of the scale allocated from 1 to 5 , which depicts the range from "strongly disagree" to "strongly agree". The study constructs were measured with valid and reliable scales in the literature and modified to fit the context. In operationalizing information motive, the study used three items adapted from Jung, Kim, and Kim (2014). The entertainment motive was operationalized with three items adapted from Shao and Ross (2015). The social interaction motive was measured by borrowing three items from Chiu, Hsu, and Wang (2006). The multidimensional concept of customer engagement was measured by adapting items from Solem and Pedersen (2016). 
Ranaweera, Hasini Virajini and de Silva, Thanuka Mahesha

Table 1: Respondent Characteristics

\begin{tabular}{lrc}
\hline Respondent characteristics & Frequency $(n)$ & Percent \\
\hline Gender & & \\
Male & 117 & 45.3 \\
Female & 141 & 54.7 \\
Age & & \\
$18-20$ & 5 & 2.0 \\
$21-23$ & 85 & 32.9 \\
$24-28$ & 168 & 65.1 \\
Time spent on Facebook per log-in & & \\
Less than 1 hour & 33 & 12.8 \\
1-2 hours & 94 & 36.4 \\
3-4 hours & 74 & 28.7 \\
Above 4 hours & 57 & 22.1 \\
FFBP visiting frequency & & \\
Daily & 88 & 34.1 \\
Weekly & 128 & 49.6 \\
Monthly & 41 & 15.9 \\
Yearly & 1 & 0.4 \\
\hline Notes: FBP - Facebook brand page, FFBP- Fashion Facebook brand page
\end{tabular}

\section{Data Analysis and Findings}

\section{Data Screening and Descriptive Statistics}

The data were first assessed with SPSS 21.0 to test the multivariate assumptions of normality, linearity, homoscedasticity, and multicollinearity. The skewness and kurtosis values ranged between -2.00 and +2.00 , ensuring that the data were normally distributed. The linearity and homoscedasticity assessed with curve estimation and scatterplots using SPSS 21.0, and the results indicated that data met the requirements in the literature (Hair, Black, Babin, \& Anderson, 2014). Additionally, multicollinearity of all the constructs was assessed with variance inflation factor and found that the highest value recorded among the constructs was 3.436, suggesting the assumption of multicollinearity was not violated following the cut-off value of 10 (Hair et al., 2014). Then, the constructs were factor analysed with SPSS 21 to determine the underlying structure of constructs. Accordingly, all the items loaded separately on the respective constructs.

The Kaiser-Meyer-Olkin (KMO) measure was 0.908, which exceed the minimum acceptable value of 0.5 , and Bartlett's Test of Sphericity was significant $(p<0.05)$. After the data screening, descriptive statistics of mean and standard deviation (SD) of scale items were further computed. The factor loading, mean and SD are presented in Table 2. 
South Asian Journal of Business Insights

Table 2: Factor Loadings

\begin{tabular}{|c|c|c|c|}
\hline Items & $\begin{array}{l}\text { Factor } \\
\text { loading }\end{array}$ & Mean & SD \\
\hline \multicolumn{4}{|l|}{ Information } \\
\hline The information on this FBP is helpful for me & .775 & 3.74 & .985 \\
\hline The information on this FBP is useful for me & .772 & 3.66 & .974 \\
\hline $\begin{array}{l}\text { I think a benefit of this Facebook brand page is the } \\
\text { ability to acquire information inexpensively }\end{array}$ & .843 & 3.79 & .990 \\
\hline \multicolumn{4}{|l|}{ Entertainment } \\
\hline This FBP is entertaining & .671 & 3.42 & .944 \\
\hline This FBP is fun & .808 & 3.09 & .988 \\
\hline This FBP is exciting & .703 & 3.36 & .911 \\
\hline \multicolumn{4}{|l|}{ Social interaction } \\
\hline $\begin{array}{l}\text { Interacting with this FBP helps me maintain social } \\
\text { relationships }\end{array}$ & .788 & 3.24 & .945 \\
\hline $\begin{array}{l}\text { Interacting with this FBP makes me emotionally } \\
\text { attached }\end{array}$ & .774 & 3.18 & .995 \\
\hline $\begin{array}{l}\text { Interacting with this FBP enhances my social } \\
\text { relationships }\end{array}$ & .810 & 3.29 & .935 \\
\hline \multicolumn{4}{|l|}{ Cognition } \\
\hline On the FBP, my mind is very focused on the brand & .743 & 3.54 & .942 \\
\hline $\begin{array}{l}\text { On the FBP, I focus a great deal of attention to the } \\
\text { brand }\end{array}$ & .702 & 3.60 & .882 \\
\hline $\begin{array}{l}\text { On the FBP, I become absorbed by the brand } \\
\text { Affection }\end{array}$ & .586 & 3.47 & .942 \\
\hline I am enthusiastic towards this FBP & .621 & 3.40 & .823 \\
\hline I feel energetic when in contact with this FBP & .714 & 3.42 & .875 \\
\hline \multicolumn{4}{|l|}{ Activation } \\
\hline I exert my full effort in supporting this FBP & .763 & 3.18 & .855 \\
\hline I try my hardest to perform well on behalf of this FBP & .851 & 3.27 & .927 \\
\hline
\end{tabular}

Note: FBP - Facebook brand page

\section{Data Analysis Technique}

The data met the multivariate assumptions (Hair et al., 2014) and the minimum sample size requirements (Stevens, 2009; Hair et al., 2014), so that the covariance-based structural equation modeling (CB-SEM) with AMOS 21.0 was used to further analysis of data. A two-step procedure was used, in which the measurement model was first assessed and then the hypothesized relationships were tested with the structural model. 
Ranaweera, Hasini Virajini and de Silva, Thanuka Mahesha

\section{Measurement Model}

Following a confirmatory factor analysis (CFA) using AMOS 21.0, the measurement model was assessed with goodness of- fit index (GFI), comparative fit index (CFI), incremental fit index (IFI), Tucker-Lewis index (TLI), the root mean square error of approximation (RMSEA), and $\chi 2 / d f$ value, and the model fit was established following the cut-off values suggested by Hair et al. (2014). All the study constructs were treated as reflective models due to the items used to measure each construct were centred on a single theme. The fit indices indicated a satisfactory fit to the data $\left(\chi^{2} / \mathrm{df}=2.295, \mathrm{GFI}=.913, \mathrm{IFI}=.952, \mathrm{TLI}=.935\right.$, $\mathrm{CFI}=.952$, RMSEA=0.071). The discriminant and convergent validity of the constructs were established following Fornell and Larcker (1981). The reliability of the constructs was assessed and established using Cronbach's alpha and composite reliability (CR), where values above 0.70 are considered to be satisfactory (Bagozzi \& Yi, 1988). The results presented in Table 3 indicate that convergent validity was satisfied following the average variance extracted (AVE) values above 0.50, and Cronbach's alpha and CR values above 0.70. Also, the square root of AVE of each construct is above their inter-construct correlations (Fornell \& Larcker, 1981), supporting discriminant validity.

Table 3: Reliability and Validity

\begin{tabular}{|c|c|c|c|c|c|c|c|c|c|}
\hline Variable & $\mathrm{CA}$ & CR & AVE & INF & ENT & SOI & COG & AFF & ACT \\
\hline $\begin{array}{l}\text { Information } \\
\text { (INF) }\end{array}$ & 0.887 & 0.887 & 0.724 & 0.85 & & & & & \\
\hline $\begin{array}{l}\text { Entertainment } \\
\text { (ENT) }\end{array}$ & 0.763 & 0.761 & 0.517 & 0.676 & 0.72 & & & & \\
\hline $\begin{array}{l}\text { Social } \\
\text { interaction (SI) }\end{array}$ & 0.859 & 0.866 & 0.683 & 0.565 & 0.643 & 0.83 & & & \\
\hline $\begin{array}{l}\text { Cognition } \\
\text { (COG) }\end{array}$ & 0.824 & 0.828 & 0.617 & 0.766 & 0.710 & 0.667 & 0.78 & & \\
\hline Affection (AFF) & 0.751 & 0.753 & 0.605 & 0.761 & 0.648 & 0.711 & 0.730 & 0.78 & \\
\hline $\begin{array}{l}\text { Activation } \\
\text { (ACT) }\end{array}$ & 0.804 & 0.807 & 0.676 & 0.518 & 0.594 & 0.632 & 0.690 & 0.713 & 0.82 \\
\hline
\end{tabular}

Notes: CA - Cronbach's alpha CR - Composite reliability; AVE - Average variance extracted Bold diagonal values represent the square root of AVE, which should be above the offdiagonal inter-construct correlations for establishing discriminant validity

\section{Structural Model}

After assessing the model fit of the measurement model and establishing the convergent and discriminant validity, the model fit of the structural model was assessed. The structural model evaluation presented the following acceptable fit indices $(\chi 2 / \mathrm{df}=2.478, \mathrm{GFI}=.904$, $\mathrm{IFI}=.945, \mathrm{TLI}=.926, \mathrm{CFI}=.944$, RMSEA=0.076). The AMOS output for structural model is shown in Figure 2. 


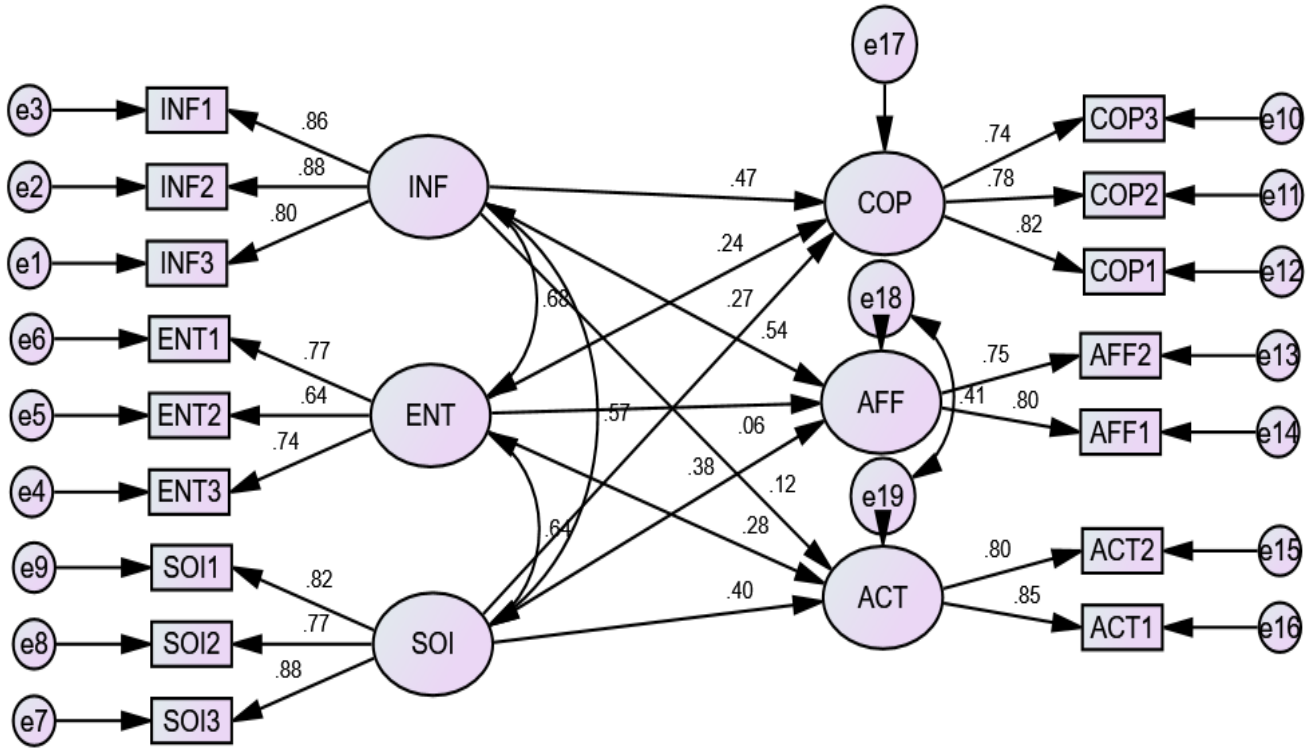

Figure 2: Structural Model

As per the results shown in Table 4, information had a significant influence on cognition $(B=.47, p<0.001)$ and affection $(B=.54, p<0.001)$, hence, supporting hypothesis $H 1 a$ and $H 1 b$ respectively. However, the results revealed that activation was not influenced by information $(B=.12, p>0.05)$, not supporting $H 1 c$. As per the results, entertainment had an influence on cognition $(B=.24, p<0.05)$ and activation $(B=.27, p<0.05)$, hence, supporting $\mathrm{H} 2 \mathrm{a}$ and $\mathrm{H} 2 \mathrm{c}$ respectively. However, the results revealed that affection was not influenced by entertainment $(B=.06, p>0.05)$, not supporting $H 2 b$. Finally, the social interaction was found to be influencing cognition $(\theta=.27, p<0.001)$, affection $(\theta=.38$, $p<0.001)$, and activation $(B=.40, p<0.001)$, supporting $H 3 a, H 3 b$ and $H 3 c$ respectively.

\section{Discussion and Conclusion}

Having examined the motives of customer engagement on FFBPs using U\&G theory, the paper contributes to a deeper understanding of customer engagement within FFBPs. Accordingly, the influence of information motive, entertainment motive, and social interactional motive on the multidimensional concept of customer engagement was explored. The conceptual model and corresponding hypotheses address the dynamic nature of customer motives and their impact on components of customer engagement.

The first three research hypotheses $(\mathrm{H} 1 \mathrm{a}, \mathrm{H} 1 \mathrm{~b}$ and $\mathrm{H} 1 \mathrm{C}$ ) focused on the impact of information on the three dimensions of customer engagement. According to scholars, the use of information posts is considered to be an effective message strategy on FBPs, 
Ranaweera, Hasini Virajini and de Silva, Thanuka Mahesha

especially to drive customer engagement (Leung, Tanford, \& Jiang, 2017; Vale \& Fernandes, 2018; de Silva, 2019a).

Table 4: Hypotheses Testing Results

\begin{tabular}{|c|c|c|c|c|}
\hline Path & & Hypothesis & 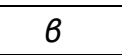 & Supported? \\
\hline $\begin{array}{l}\text { Information } \\
\text { Cognition }\end{array}$ & $\rightarrow$ & H1a & $0.47^{* *}$ & Yes \\
\hline $\begin{array}{l}\text { Information } \\
\text { Affection }\end{array}$ & $\rightarrow$ & $H 1 b$ & $0.54^{* *}$ & Yes \\
\hline $\begin{array}{l}\text { Information } \\
\text { Activation }\end{array}$ & $\rightarrow$ & $H 1 c$ & 0.12 & No \\
\hline $\begin{array}{l}\text { Entertainment } \\
\text { Cognition }\end{array}$ & $\rightarrow$ & $\mathrm{H} 2 \mathrm{a}$ & $0.24^{*}$ & Yes \\
\hline $\begin{array}{l}\text { Entertainment } \\
\text { Affection }\end{array}$ & $\rightarrow$ & $H 2 b$ & 0.06 & No \\
\hline $\begin{array}{l}\text { Entertainment } \\
\text { Activation }\end{array}$ & $\rightarrow$ & $H 2 c$ & $0.27^{*}$ & Yes \\
\hline $\begin{array}{l}\text { Social interaction } \\
\text { Cognition }\end{array}$ & $\rightarrow$ & H3a & $0.27^{* *}$ & Yes \\
\hline $\begin{array}{l}\text { Social interaction } \\
\text { Affection }\end{array}$ & $\rightarrow$ & $H 3 b$ & $0.38^{* *}$ & Yes \\
\hline $\begin{array}{l}\text { Social interaction } \\
\text { Activation }\end{array}$ & $\rightarrow$ & $H 3 c$ & $0.40^{* *}$ & Yes \\
\hline
\end{tabular}

As far as the influence of information motive on customer engagement is concerned, two hypotheses were accepted while one was not supported. It should be noted that the information had the greatest impact on the affection component of customer engagement. Also, the information had a considerable impact on the cognition component of customer engagement. The literature suggests that customer's information motive can positively influence the frequency of visits of FBPs (Ben-Shaul \& Reichel, 2018). Hence, customers in Sri Lanka are likely to revisit the FBP and recommend the page to others, when the FBP provides customers with information value (de Silva, 2021). However, this study discovered that information motive had no effect on the activation component of customer engagement. The literature suggests that customers do not visit FBPs as the primary source for information (Piehler, Schade, Kleine-Kalmer, \& Burmann, 2019). An indication of this was that customers of the present study who were engaged with FFBPs were not willing to actively engage such as spending time, energy, and effort on brand pages with information, which was provided through the brand pages.

The entertainment motive was found to be influencing customer engagement on FBPs (Kujur \& Singh, 2019; Vale \& Fernandes, 2018). The present study confirms two hypotheses $(\mathrm{H} 2 \mathrm{a}$ and $\mathrm{H} 2 \mathrm{c})$ about the impact of entertainment on customer engagement. However, $\mathrm{H} 2 \mathrm{~b}$ was not supported, suggesting that customers did not feel good when 
receiving more entertaining content via the FFBPs. Nevertheless, majority of the previous studies highlighted that entertainment contributed to customer engagement on FBPs (Cvijikj \& Michahelles, 2013; Kujur \& Singh, 2019; Piehler et al., 2019; de Silva, 2019b). However, some recent work highlighted that entertainment motive did not influence customer engagement in FBPs (Vale \& Fernandes, 2018; de Silva, 2019a). This study adapts social interaction motive from $U \& G$ theory to examine the influence on customer engagement. In this study, social interaction positively influenced the all three components of customer engagement; cognition, affection, and activation. The literature suggests that social interaction plays a significant role among community users in an OBC (Kuo \& Feng, 2013), and serves as the most influential factor on customer engagement in FBPs (de Silva, 2019a). It should be noted that social interaction had the greatest impact on activation out of three dimensions of customer engagement. As such, if brand pages provide more social interaction opportunities, customers are more likely to spend more time and energy on the brand page. Moreover, social interaction had effects on affection and cognition as well, signalling that marketers can benefit through offering interaction opportunities to customers on their FFBPs.

\section{Implications}

From the theoretical perspective, this study is one of the pioneering studies to present a conceptual model that explains the relationships between customer motivations and different components of customer engagement. The major contribution of the study concerns linking customer motivations to customer engagement with the theoretical underpinning of U\&G theory. Additionally, this empirical investigation offers a comprehensive model that describes the motivations of customer engagement through the use of U\&G theory (Ku et al., 2013). Notably, as highlighted before, this study is one of the pioneering studies to investigate the motives of customer engagement with the multidimensional concept of customer engagement. As such, the study identified customer engagement as a multidimensional concept and characterized by cognition, affection, and activation. Drawing on the U\&G theory, the study attempted to analyse the effects of information, entertainment, and social interaction motives on cognition, affection, and activation dimensions of customer engagement in the context of FFBPs.

From the managerial perspective, managers are advised to focus on offering information, entertainment, and social interaction content via FBPs. Informational content such as new features, promotion information, and opinions of experienced users could be used to attract customers in the good mood and motivate them to return to the brand page. Moreover, customers can be attracted to visit the brand page by offering entertainment content, thereby increasing the likelihood of engaging on the brand page. As such, managers can provide entertainment benefits such as photos, videos, recreation, fun, and emotional release via their FBP. Moreover, offering more social interaction opportunities to increase the interactions between customers are also recommended. Social interaction motive can be fulfilled by providing more interaction opportunities, including customer-to- 
Ranaweera, Hasini Virajini and de Silva, Thanuka Mahesha

customer interactions and additional social characteristics that are valued by the customers.

\section{Limitations and Future Research Directions}

Although the study makes a consequential contribution to the literature, the study is still subject to some limitations. The study used a convenience sample of undergraduates in Sri Lanka and focused only on FFBPs. In future, studies are needed on different types of FBPs to identify the influence of customer motivations on different dimensions of customer engagement. Moreover, future research can investigate through the use of different gratifications of U\&G theory in determining the motivations of customer engagement. Furthermore, the study was limited to Facebook; however, there are multiple social media platforms on which brands interact with customers. Therefore, it is suggested for future research to replicate this conceptual model on other social media platforms.

\section{References}

Anabel, Q. H. (2012). Is the uses and gratifications approach still relevant in a digital society? Theoretical and methodological applications to social media. Journal of Mass Communication \& Journalism, 2 (7) , 1-3.

Arenas, J. G., Ramirez, P. E., \& Rondan, F. G. (2013). Social identity, electronic word-ofmouth and referrals in social network services. Kybernetes, 42 (8), 1149-1165.

Bagozzi, R., \& Yi, Y. (1988).On the evaluation of structural equation models. Journal of the Academy of Marketing Science, 16 (1), 74-94.

Baird, C., \& Parasnis, G. (2011). From social media to social customer relationship management. Strategy \& Leadership, 39 (5), 30-37.

Barger, V., Peltier, J. W., \& Schultz, D. E. (2016). Social media and consumer engagement: a review and research agenda. Journal of Research in Interactive Marketing, 10 (4), 268-287.

Ben-Shaul, M. \& Reichel, A. (2018). Motives, modes of participation, and loyalty intentions of Facebook tourism brand page consumers research agenda. Journal of Travel Research, 57 (4), 453-471.

Beukeboom, C. J., Kerkhof, P., \& Vries, M. D. (2015). Does a virtual like cause actual liking? How following a brand's Facebook updates enhances brand evaluations and purchase intention. Journal of Interactive Marketing, 32, 26-36.

Brodie, R. J., Ilic, A., Juric, B., \& Hollebeek, L. (2013). Consumer engagement in a virtual brand community: An exploratory analysis. Journal of Business Research, 66 (1), 105-114.

Carlson, J., Rahman, M.M., Taylor, A., Voola, R. (2019). Feel the VIBE: examining value in the brand page experience and its impact on satisfaction and customer engagemnt bhaviours in mobile social media. Journal of Retail Consumer Service, 46, 149-162. 
Carlson, J., Wyllie, J., Rahman, M.M., Voola, R. (2019). Enhancing brand relationship performance through customer participation and valu ecreation in socil media brand communitis. Journal of Retail Consumer Service 50 (September), 333-341.

Chang, S., \& Fan, S. (2017). Cultivating the brand-customer relationship in Facebook fan pages: A study of the fast-fashion industry. International Journal of Retail and Distribution Management, 45 (3), 53-270.

Cheung, C.M.K., Chiu, P.Y., \& Lee, M.K.O. (2011). Online social networks: why do students use Facebook? Computers in Human Behavior, 27 (4), 1337-1343.

Cheung, M.L., Pires, G. \& Rosenberger, P.J. (2020). The influence of perceived social media marketing elements on consumer-brand engagement and brand knowledge. Asia Pacific Journal of Marketing and Logistics, 32 (3), 695-720.

Chiu, C. M., Hsu, M. H., \& Wang, E. T. (2006). Understanding knowledge sharing in virtual communities: An integration of social capital and social cognitive theories. Decision Support Systems, 42 (3), 1872-1888.

Choi, T.M., Liu, N., Liu, S. C., Mak, J., \& To, Y.T. (2010). Fast fashion brand extensions: an empirical study of consumer preferences. Journal of Brand Management, 17 (7), 472-487.

Chu, S., \& Kim, Y. (2011). Determinants of consumer engagement in electronic word-ofmouth (eWOM) in social networking sites. International Journal of Advertising, 30 (1), 47-75.

Curran, J., \& Lennon, R. (2011). Participating in the conversation: Exploring the usage of social media networking sites. Academy of Marketing Studies Journal, 15 (1), 21 39.

Cvijikj, I.P. \& Michahelles, F. (2013). Online engagement factors on Facebook brand pages. Social Network Analysis and Mining, 3 (4), 843-861.

Daugherty, T., Eastin, M., \& Bright, L. (2008). Exploring consumer motivations for creating user-generated content. Journal of Interactive Advertising, 8 (2), 16-25.

de Silva, T. M. (2019a). Building relationships through customer engagement in Facebook brand pages. Marketing Intelligence and Planning, 38 (6), 713-729. http://doi.org/10.1108/MIP-02-2019-0085.

de Silva, T. M. (2019b). Customer engagement in Facebook brand pages, In Proceedings of the $\mathcal{8}^{\text {th }}$ International Conference on Management and Economics, $14^{\text {th }}$ August 2019, University of Ruhuna, Matara, Sri Lanka, 83-106.

de Silva, T. M. (2021). The role of customer engagement in cultivating relationships with automotive Facebook brand pages. Online Information Review, 45 (7), 13621380. https://doi.org/10.1108/oir-11-2019-0352.

de Vries, L., Gensler, S., \& Leeflang, P. (2012). The Popularity of brand posts on brand fan pages: an investigation of the effects of social media marketing", Journal of Interactive Marketing, 26 (2), 83-91.

Dessart, L., Veloutsou, C. \& Morgan-Thomas, A. (2015). Consumer engagement in online brand communities: a social media perspective. The Journal of Product and Brand Management, 24 (1), 28-42. 
Ranaweera, Hasini Virajini and de Silva, Thanuka Mahesha

Dimitiadis, S., \& Tsimonis, G. (2014). Brand strategies in social media. Marketing Intelligence and Planning, 32 (3), 328-344.

Dolan, R., Conduit, J., Fahy, J., \& Goodman, S. (2016). Social media engagement behaviour: a uses and gratifications perspective. Journal of Strategic Marketing, 24 (3-4), 261277.

Dwivedi, A. (2015). A higher-order model of consumer brand engagement and its impact on loyalty intentions. Journal of Retailing and Consumer Services, 24, 100-109.

Enginkaya, E., \& Yilmaz, H. (2014). What drives consumers to interact with brands through social media? A motivation scale development study procedia. Social and Behavioral Sciences, 148 (1), 219-226.

Fornell, C., \& Larcker, D. (1981). Evaluating structural equation models with unobservable variables and measurement error. Journal of Marketing Research, 18 (1), 39-50.

Frimpong, O. K., \& McLean, G. (2018). Examining online social brand engagement: a social presence theory perspective. Technological Forecasting and Social Change, 128, 10-21.

Gopura, S. \& Kothalawala, L. (2021). Confused Customer: Sizing and Styling Related Matters in Online Fashion Shopping in Sri Lanka. Open Journal of Social Sciences, 9 , 110-127.

Habibi, M., Laroche, M., \& Richard, M. (2014). The roles of brand community and community engagement in building brand trust on social media. Computers in Human Behavior, 37, 152-161.

Hair, J. F., Black, W. C., Babin, B. J. \& Anderson, R. E. (2014). Multivariate Data Analysis (7th ed.), Pearson, London.

Hicks, A., Comp, S., Horovitz, J., Hovarter, M., Miki, M., \& Beven, J. L. (2012). Why people use Yelp.com: an exploration of uses and gratifications.Computers in Human Behavior, 28 (6), 2274-2279.

Hoekstra, J. C., Huizzingh, E. K., Bijmolt, T. H., \& Krawczyk, A. C. (2015). Providing information and enabling transactions: which website function is more important for success. Journal of Electronic Commerce Research, 16 (2), 81-94.

Hollebeek, L. D. (2011). Demystifying customer brand engagement: exploring the loyalty nexus. Journal of Marketing Management, 27 (7/8), 785-807.

Hollebeek, L., Juric, B., \& Tang, W. (2017). Virtual brand community engagement practices: arefined typology and model. Journal of Services Marketing, 31 (3), 204-217.

Ismail, A.R. (2017). The influence of perceived social media marketing activities on brand loyalty: the mediation effect of brand and value consciousness. Asia Pacific Journal of Marketing and Logistics, 29 (1), 129-144.

Jahn, B., \& Kunz, W. (2012). How to transform consumers into fans of your brand. Journal of Service Management, 23 (3), 344-361.

Jung, N. Y., Kim, S., \& Kim, S. (2014).Influence of consumer attitude toward online brand community on revisit intention and brand trust. Journal of Retailing and Consumer Services, 21 (4), 581-589. 
Kang, J. Y., \& Johnson, K. K. (2015). Commerce platform for apparel online social shopping: testing a mowen's 3M model. International Journal of Information Management, 35 (6), 691-701.

Katz, E., \& Foulkes, D. (1962). On the use of the mass media as 'escape': clarification of a concept. The Public Opinion Quarterly, 26 (3), 377-388.

Ko, H., Cho, C. H., \& Roberts, M. S. (2005). Internet uses and gratifications: A structural equation model of interactive advertising. Journal of Advertising, 34 (2), 57-70.

Kujur, F., \& Singh, S. (2019). Antecedents of the relationship between customers and organizations developed through social networking sites. Management Research Review, 42(1), 2-24.

Kuo, Y. F., \& Feng, L. H. (2013). Relationships among community interaction characteristics, perceived benefits, community commitment, and oppositional brand loyalty in online brand communities. International Journal of Information Management, 33 (6), 948-962.

$\mathrm{Ku}$, Y.C., Chu, T. H., \& Tseng, C. H. (2013) Gratifications for using CMC technologies: a comparison among SNS, IM, and email. Computers in Human Behavior, 29 (1), 226234.

Lee, C., \& Ma, L. (2012). News sharing in social media: the effect of gratifications and prior experience. Computers in Human Behavior, 28 (2), 331-339.

Lee, Z. W., Chan, T. K., Chong, A. Y. L., Thadani D. R. (2019). Customr engagement through omnichannel retailing: the ffects of channel intergration quality. Indian Journal of Markeing Management, 77, 90-101.

Leung, X., Tanford, S., \& Jiang, L. (2017). Is a picture really worth a thousand words? An experiment on hotel Facebook message effectiveness. Journal of Hospitality and Tourism Technology, 8 (1), 19-38.

Lima, V. M., Irigaray, H. A., \& Lourenco, C. (2018). Consumer engagement on social media: insights from a virtual brand community: Qualitative Market Research. An International Journal, 22 (1), 14-32.

Lipsman, A., Mudd, G., Rich, M., \& Bruich, S. (2012). The power of 'like': how brands reach (and influence) fans through social media marketing. Journal of Advertising Research, 52 (1), 40-52.

Manthiou, A., Chiang, L., Tang, L.R., (2013). Identifying and responding customer needs on Facebook fan pages. International Journal of Technology Human Inteaction, 9 (3), 36-52.

McCormick, H., \& Livett, C. (2012). Analyzing the influence of the presentation of fashion garments on young consumers' online behavior. Journal of Fashion Marketing and Management, 16 (1), 21-41.

Mochon, D., Johnson, K., Schwartz, J., \& Ariely, D. (2017).What are likes worth? A Facebook page field experiment. Journal of Marketing Research, 54 (2), 306-317.

Muniweera, C. D. W., Balawardhana, K. P. I. A., Rajapaksha, M. S. N., Chamara, M. A. D. S., \& Jayasuriya, N.A. (2020). The Importance of Factors Influencing on e-WOM Engagement towards Consumer Purchase Intention in Clothing Retailers, Sri Lanka. International Journal of Academic Research in Business and Social Sciences, 10(5), 349-360. 
Ranaweera, Hasini Virajini and de Silva, Thanuka Mahesha

Muntinga, D. G., Moorman, M., \& Smit, E. G. (2011). Introducing COBRAs: Exploring motivations for brand-related social media use. International Journal of Advertising, 30 (1), 13-46.

Nyadzayo, M. W., Leckie, C., \& Johnson, L. W. (2016). Antecedents of consumer brand engagement and brand loyalty. Journal of Marketing Management, 32 (5/6), 558578.

Pansari, A., \& Kumar, V. (2017). Customer engagement: the construct, antecedents, and consequences. The Journal of the Academy of Marketing Science, 45 (3), 294-311.

Parihar, P., Dawra, J., \& Sahay, V. (2018). The role of customer engagement in the involvement-loyalty link. Marketing Intelligence and Planning, 37 (1), 66-79.

Park, N., Kee, K., \& Valenzuela, S. (2009). Being immersed in social networking environment: Facebook groups, uses and gratifications, and social outcomes. CyberPsychology and Behavior, 12 (6), 729-733.

Peters, K., Chen, Y., Kaplan, A. M., Ognibeni, B., \& Pauwels, K. (2012).Social media metrics - A framework and guidelines for managing social media. Journal of Interactive Marketing, 27 (4), 81-298.

Piehler, R., Schade, M., Kleine-Kalmer, B. \& Burmann, C. (2019). Consumers' online brandrelated activities (COBRAs) on SNS brand pages. European Journal of Marketing, 53(9), 1833-1853, doi: 10.1108/EJM-10-2017-0722.

Porat, T., \& Tractinsky, N. (2012). It's a pleasure buying here: the effects of web-store design on consumers' emotions and attributes. Human-Computer Interaction, 27 (3), 235-276.

Poyry, E., Parvinen, P. \& Malmivaara, T. (2013). Can we get from liking to buying? Behavioral differences in hedonic and utilitarian Facebook usage. Electronic Commerce Research and Applications, 12 (4), 224-235.

Raacke, J., \& Bonds, J. R. (2008). MySpace and Facebook: Applying the uses and gratifications theory to exploring friend-networking sites. CyberPsychology and Behavior, 11(2), 169-174.

Rajapaksha, L., \& Thilina, D. (2019). The influence of Facebook brand page on consumer purchase intention with reference to fashion retailing industry. Sri Lanka Journal of Marketing, 5 (1).

Richard, J., \& Zhang, A. (2012). Corporate image, loyalty, and commitment in the consumer travel industry. Journal of Marketing Management, 28 (5/6), 568-593.

Rodriguez, T. E., \& Fernandez, R. B. (2016). Facebook practices for business communication among fashion retailers. Journal of Fashion Marketing and Management, 21 (1), 33-50.

Rohm, A., Kaltcheva, V., \& Milne, G. (2013). A mixed approach to examining brandconsumer interactions driven by social media. Journal of Research in Interactive Marketing, 7 (4), 295-311.

Schaller, T., Malhotra, N., \& Patil, A. (2017). Common method variance in advertising research: when to be concerned and how to control for it. Journal of Advertising, 46 (1), 193-212. 
Schau, H., \& Gilly, M. (2003). We are what we post? self-presentation in personal webspace. Journal of Consumer Research, 30 ( 3), 385-404.

Seo, E.J., \& Park, J.W. (2018). A study of th effects of social media marketing activities on brand equity and customer response in the airline industry. Journal of Air Transort Management, 66, 36-41.

Shao, G. (2009). Understanding the appeal of user-generated media: A uses and gratifications perspective. Internet Research, 19(1), 7-25.

Shao, W., \& Ross, M. (2015). Testing a conceptual model of Facebook brand page communities. Journal of Research in Interactive Marketing, 9 (3), 239-258.

Shukla, A., Sharma, N. K., \& Swami, S. (2011).Web site classification on information and entertainment profiles. Journal of Advances in Management Research, 8 (1), 148157.

Smock, A. D., Ellison, N. B., Lampe, C., \& Wohn, D. Y. (2011). Facebook as a toolkit: a uses and gratification approach to unbundling feature use. Computers in Human Behavior, 27 (6), 2322-2329.

Solem, B. A., \& Pedersen, P. E. (2016). The role of customer brand engagement in social media: conceptualization, measurement, antecedents, and outcomes. International Journal of Internet Marketing and Advertising, 10 (4), 223-254.

Song, J., Moon, H., \& Kim, M. (2019). When do customers engage in brand pages? effects of social presence. International Journal of Contemporary Hospitality Management, 31 (9), 3627-3645.

Stevens, J.P. (2009). Applied multivariate statistics for the social sciences. Routledge, New York, NY.

Tafesse, W. (2015). Content strategies and audience response on Facebook brand pages. Marketing Intelligence and Planning, 33 (6), 927-943.

Tsai, W.H.S., \& Men, L.R. (2017). Consumer engagement with brands on social network sites: a cross-cultural comparison of China and the USA. Journal of Marketing Communications, 23 (1), 2-22.

Vale, L., \& Fernandes, T. (2018). Social media and sports: driving fan engagement with football clubs on Facebook. Journal of Strategic Marketing, 26 (1), 37-55.

Whiting, A. \& Williams, D. (2013). Why people use socil media: a uses and gratifications approach. Qulitative Market Research: An International Journal, 16 (4), 362-369.

Zaglia, M. E. (2013). Brand communities embedded in social networks. Journal of Business Research, 66 (2), 216-223. 


\section{Author Biography}

Hasini Virajini Ranaweera was a Former Sales Intern at Ceylon Biscuits Limited (CBL), and she was a Youth Forum Volunteer at American Corner Matara, Sri Lanka. She played the role of Karate Captain for the Faculty of Management and Finance, University of Ruhuna in 2018. She graduated from the University of Ruhuna in 2020 with a Bachelor's Degree in Marketing Management. She is reading for the Postgraduate Diploma in Marketing at SLIM Business School, Matara.

Thanuka Mahesha de Silva is a Lecturer in the Department of Marketing at the University of Ruhuna, Sri Lanka. His research interests lie in the areas of customer engagement, social media marketing, and brand management. His publications have appeared in indexed journals including Marketing Intelligence \& Planning and Online Information Review. 